\title{
ジャークー定減速を想定した列車運転士のブレ一キ操作支援システム*
}

\author{
丸茂 喜高 ${ }^{* 1}$, 佐藤 洋康 ${ }^{* 2}$, 綱島 均 ${ }^{* 1}$, 小島 崇*3
}

\section{Braking Assistance System for Train Drivers by Considering Deceleration with Constant Jerk}

\author{
Yoshitaka MARUMO ${ }^{* 1}$, Hiroyasu SATO, Hitoshi TSUNASHIMA and Takashi KOJIMA \\ ${ }^{* 1}$ College of Industrial Technology, Nihon University \\ 1-2-1 Izumi-cho, Narashino-shi, Chiba 275-8575, Japan
}

This study examines the braking assistance system for train drivers when stopping at a station to prevent the drivers from overrunning. The conventional assistance system informed the driver visually of a predicted stopping position based on present vehicle velocity and deceleration. The driver with the conventional assistance system made the vehicle stop with large deceleration because the conventional assistance system calculated the predicted stopping position by considering the constant deceleration. The assistance system this study proposes considers the deceleration with constant jerk, i.e. the deceleration gradually decreases. Train-driving simulator experiments are examined with several subjects who are required train driving with the mental calculation which assumes the mental workload. Subjects with the proposed assistance system can operate the brake handle smoothly, and make the vehicle stop with small deceleration. Subjects with the conventional assistance system, on the other hand, cannot release the brake handle, and make the vehicle stop with large deceleration.

Key Words : Driver Assist, Active Safety, Maneuverability, Human Interface, Man-Machine System, Train Driver, Braking Behavior, Mental Workload

\section{1. 緒 論}

鉄道輸送は，自動車と比較して地球環境への負荷が低い反面，一度に多くの人員を輸送する性質上，より一層 の安全性が求められる. 最近発生した脱線事故に着目すると, 運転士の運転以外一の注意により生じた速度超過 によるものなどのヒューマンエラーに起因する部分が大きい(1), (2). 列車運転におけるヒューマンエラーをバック アップするシステムとして, 自動列車停止装置（ATS）などがあげられる. これらの装置により, ヒューマンエ ラーが発生した場合でも，事故を未然に防ぐことができる。しかし，ATS が作動しないような軽微なオーバーラ ンは，それ自体直接事故を引き起こすものではないが，停止位置を修正することによるダイヤの遅れやオーバー ランした事実が運転士のプレッシャーとなり，重大な事故を引き起こす要因となる可能性が考えられる(2).

そこで筆者らは，駅停止時に簡便にオーバーランを防止するための運転支援システムについて，運転シミュレ 一タ実験により検討した ${ }^{(3)}$.このシステムは, 図 1 に示すように, 駅停止時に運転士に対して, 現在の減速度を 維持した際に予想される停止位置を視覚的に呈示して，ブレーキ操作の支援を行うものである，その際，予想停 止位置が目標停止位置の手前の場合には緑色，目標停止位置を超えてオーバーランする場合には赤色で呈示する ことにより，予想停止位置の認知の支援に加えて，ブレーキ操作の判断の支援も行う。運転シミュレータ実験に より，運転支援システムを用いることでブレーキ操作が円滑に行われることを確認した ${ }^{(3)}$.

しかし，このシステムでは，予想停止位置の計算において等加速度運動を想定しているが，実際のブレーキ操

\footnotetext{
* 原稿受付 2012 年 2 月 7 日

*1 正員, 日本大学生産工学部（广275-8575 千葉県習志野市泉町 1-2-1）

*2 日本大学大学院 (

*3 正員，鉄道総合技術研究所車両構造技術研究部（干185-8540 東京都国分寺市光町 2-8-38)

E-mail: marumo.yoshitaka@nihon-u.ac.jp
} 
作では，乗客の乗り心地等の関係から，目標とする停止位置に近付くにつれ，徐々にブレーキを緩めて停止する ことが一般的である，そのような操作は運転士に委ねられており，運転支援システムによりブレーキ操作は円滑 になったものの, 停止時に比較的強い減速度で停止する場面が見られた。 そこで本研究では, 減速度が一定で減 少する条件を考慮して，ブレーキを緩めながら停止する支援を行い，その効果について運転シミュレータ実験に より検討する.

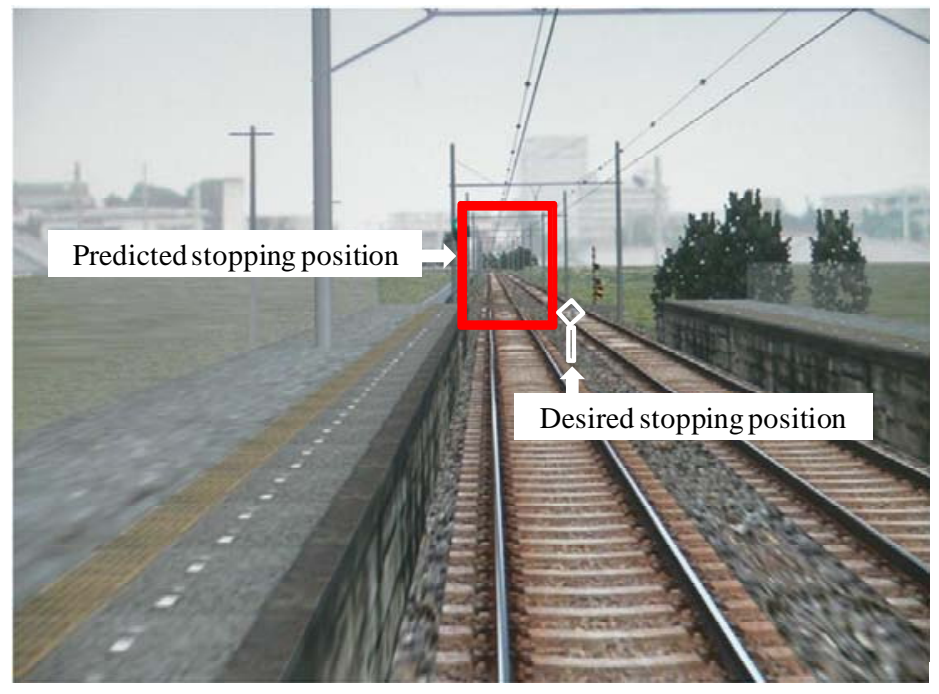

Fig. 1 Image of predicted stopping position

\section{2. ジャークー定減速を想定した予想停止位置呈示}

本研究では, 段階的にブレーキを緩める減速をジャーク (加々速度)一定で減速度が減少するものと仮定する. 予想停止位置の算出方法は, 従来と同様に等加速度運動を想定し, 従来予想停止位置が緑色で呈示されていた領 域, すなわち目標停止位置よりも手前の状態であっても, ジャーク一定で減速度を減少させて停止できない場合 には，予想停止位置を黄色で呈示するものとする.

ここで, 黄色で呈示する領域を定義するために, 減速度一定で減速する場合とジャーク一定で減速する場合の 車両の停止距離について考える. 計算過程の詳細は末尾の付録に記載されているが，いずれの条件も初期值は, 速度 $v(0)=v_{0}$, 加速度 $a(0)=a_{0}$ （ただし， $a_{0}<0 ）$ とすると, 減速度一定で減速する場合の停止距離 $d_{a}$ は以下のよ うになる。

$$
d_{a}=-\frac{v_{0}^{2}}{2 a_{0}}
$$

また, ジャーク一定で減速する場合の停止距離 $d_{j}$ は, 停止時の減速度を 0 とおくことにより, ジャークの值に よらず以下のように表すことができる.

$$
d_{j}=-\frac{2 v_{0}^{2}}{3 a_{0}}
$$

減速度一定の場合の停止距離に対するジャーク一定減速時の停止距離の比は

$$
\frac{d_{j}}{d_{a}}=\frac{-\frac{2 v_{0}^{2}}{3 a_{0}}}{-\frac{v_{0}^{2}}{2 a_{0}}}=\frac{4}{3}
$$

となり，ジャーク一定減速の場合の方が，停止に要する距離が長くなることがわかる. 
この関係から，予想される停止位置の領域を定義する. 図 2 に予想停止位置呈示の模式図を示す．ここで，車 両はジャーク一定で咸速し，目標停止位置に停止するものとし，停止時には速度および減速度は 0 になると仮定 すると, 目標停止位置までの距離は $d_{j}$ で算出できる. しかし，予想停止位置の計算は，現在の減速度が一定と仮 定しているため, このときの予想停止位置までの距離は $d_{a}$ となる. 予想停止位置までの距離が $d_{a}$ よりも手前にあ る場合には，ジャーク一定でブレーキを緩めて目標停止位置に停止することができる．しかし，予想停止位置ま での距離が $d_{a}$ よりも奥の場合には, たとえ目標停止位置よりも手前, 寸なわち従来のシステムでは緑色で呈示さ れる領域であっても, ジャーク一定でブレーキを緩めて停止しょうとした場合には目標停止位置を超えて停止す ることになる. そこで, 予想停止位置までの距離が $d_{a}$ よりも手前の場合には, 予想停止位置の枠の色を緑色で呈 示し， $d_{a}$ より奥で目標停止位置よりも手前の場合には黄色で呈示寸る. 予想停止位置が目標停止位置を超える場 合には，従来通り赤色で呈示寸るものとする.

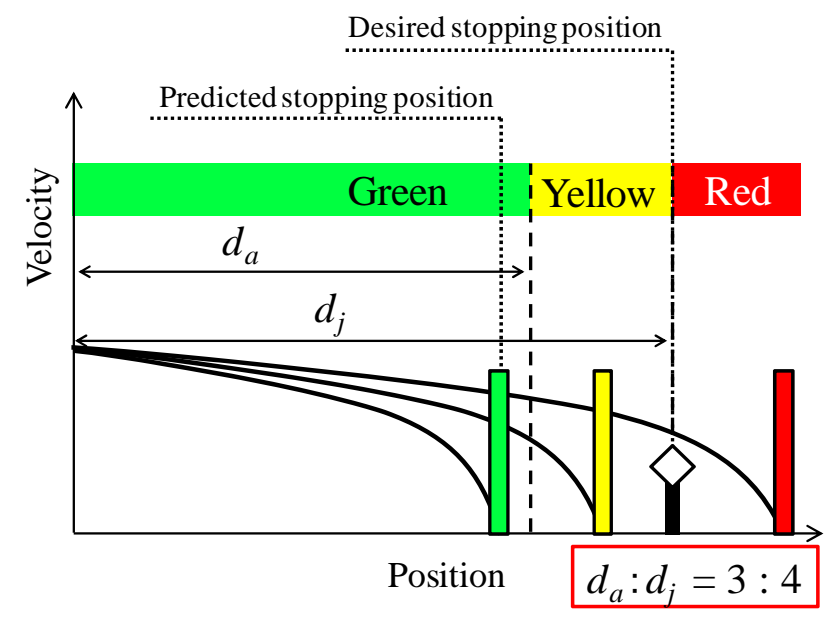

Fig. 2 Schematic diagram of predicted stopping position

\section{3. 実 験 方 法}

本研究では, 列車の運転を模擬した列車運転シミュレータ(4)（以下，シミュレータという）を用いて行った. 図 3 にシミュレータの外観を示寸，このシミュレータは，定置型であるため，加速度などの体感情報は得られな いが，2 台のプロジェクタを用いることによって被験者が偏光眼鏡を着用寸ることで立体視による前方視界を生 成していることを特徵としている.

被験者は，運転資格はないが，シミュレータの運転になれた 20 代男性 5 名（被験者 $\mathrm{A} \sim \mathrm{E}$ ）で行った. なお， 実験実施前には実験の趣旨説明とあわせてインフォームドコンセントを行った.

運転課題は，実路線を模擬した 4 駅間（それぞれの駅間を第 1 区間から第 3 区間とする）を運転し，各駅にあ る目標停止位置に列車を停止させるものとした，列車の速度は，実路線の規定速度として，本走行を行う前に十 分な練習走行を行った.

ヒューマンエラーは，運転士に心的負荷がかかっている状況で発生しやすいことから，副次課題として，心的 負荷を想定した暗算課題を被験者に課した. 暗算課題は, 3 秒毎に音声で呈示される 1 桁の数字に対して, 新た

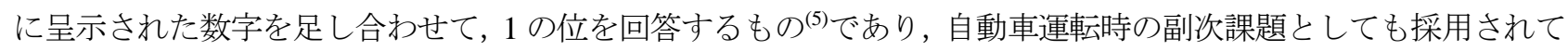
いる(6). この暗算課題を, 駅を発車して加速が終了後, 惰性走行に入ってから駅停止までの間, 被験者に課した. 運転課題と暗算課題の優先順位については，列車を所定の位置に停車させることを第一優先とした上で，可能な 限り暗算課題に回答することとした。

各被験者は，従来の運転支援システムと本研究で提案した支援システムの 2 条件について，それぞれ 2 走行ず つ行った. 


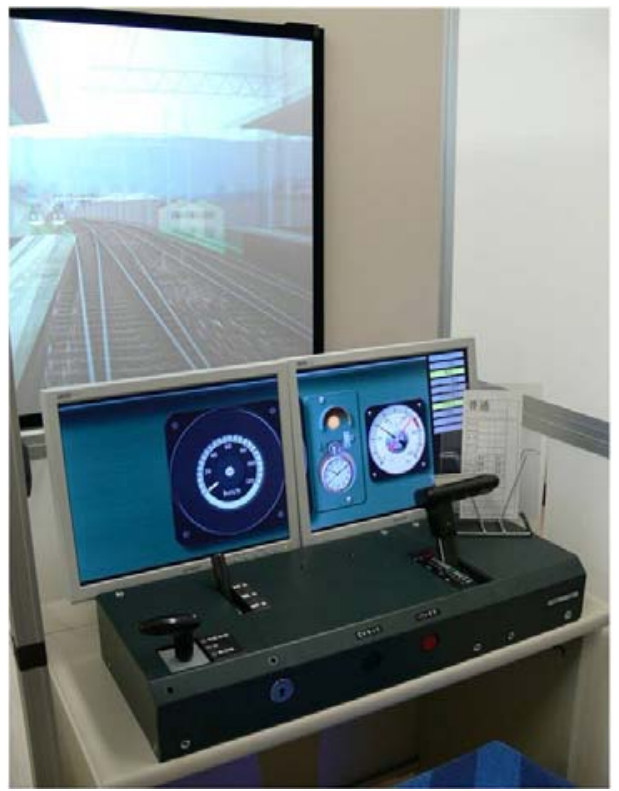

Fig. 3 Overview of train-driving simulator

\section{4. 実 験 結 果}

各システムを用いた場合の副次課題の正答率を確認したところ，すべての区間において，平均值は $60 \%$ ～ $80 \%$ 程度であり，本研究で提案した支援システムの方が，従来のシステムと比較して高く，第 1 区間および第 3 区間 でそれぞれ 5\%未満および 10\%未満の危険率で有意差が確認された。 しかし，これらの差は提案した支援システ ムの条件において，主課題である運転操作に対するリソースを低減していることが考えられるため，提案したシ ステムの効果が有利になる傾向にはないといえる．また，提案した支援システムを用いることで，結果として正 答率が上がったことも考えられるので, 以下では, 運転行動や車両状態の比較により議論を進めることにする.

\section{$4 \cdot 1 \quad$ 予想停止位置とハンドル操作の推移}

駅停止時における, 運転士の認知と操作に関係する指標として, 現在の減速度を維持した場合の予想停止位置 とブレーキ操作の推移について検討する.ここでは，一例として，被験者 A の第 2 区間の結果について示寸.

図 4 に目標停止位置までの距離に対する予想停止位置の推移を示寸，横軸は目標停止位置までの距離を示して おり，目標停止位置の手前を負とした，縦軸は予想停止位置であり，目標停止位置を 0 とし，現在の減速度を維 持すると目標停止位置を超えて停止する場合を正，手前で停止する場合を負とした．実線は本研究で提案した， ジャーク一定減速を想定した支援システムを用いた場合，破線は従来の減速度一定を想定した支援システムを用 いた場合の結果を示している．点線は予想停止位置および目標停止位置までの距離の比が 3:4 である境界を示し ており, 本研究で提案したシステムを用いた場合, 予想停止位置の值が 0 と点線の間の領域では, 予想停止位置 は黄色で呈示される，この図より，従来の支援システムを用いた場合では，減速を開始した直後において，予想 停止位置は負の值を推移しているが, $-40 \mathrm{~m}$ 付近で予想停止位置が目標停止位置付近を推移し, 余裕がない状態 で目標停止位置へ停止している，しかし，本研究で提案した支援システムでは，予想停止位置は，目標停止位置 一負の值から徐々に推移しており，点線で示した境界線付近を推移して停止していることがわかる.

次に，目標停止位置までの距離に対するブレーキ操作の推移を図 5 に示寸，横軸は目標停止位置までの距離を 示している. 縦軸はブレーキ操作を示しており，数值が高くなるほど強いブレーキがかかることになる．常用ブ レーキが 1〜7で, 非常ブレーキが 8 に対応している. この図より, 従来の支援システムを用いた場合には, ブレ 一キを段階的に緩めてはいるが， $-40 \mathrm{~m}$ 付近でブレーキを緩めたことにより，予想停止位置が目標停止位置付近 を推移してしまい, ブレーキを緩める余裕がなくなり, 目標停止位置付近まで比較的強いブレーキで停止してい る. 一方, 本研究で提案した支援システムを用いた場合には, 段階的にブレーキを緩めながら, 弱いブレーキ操 作で停止していることが確認できる. 


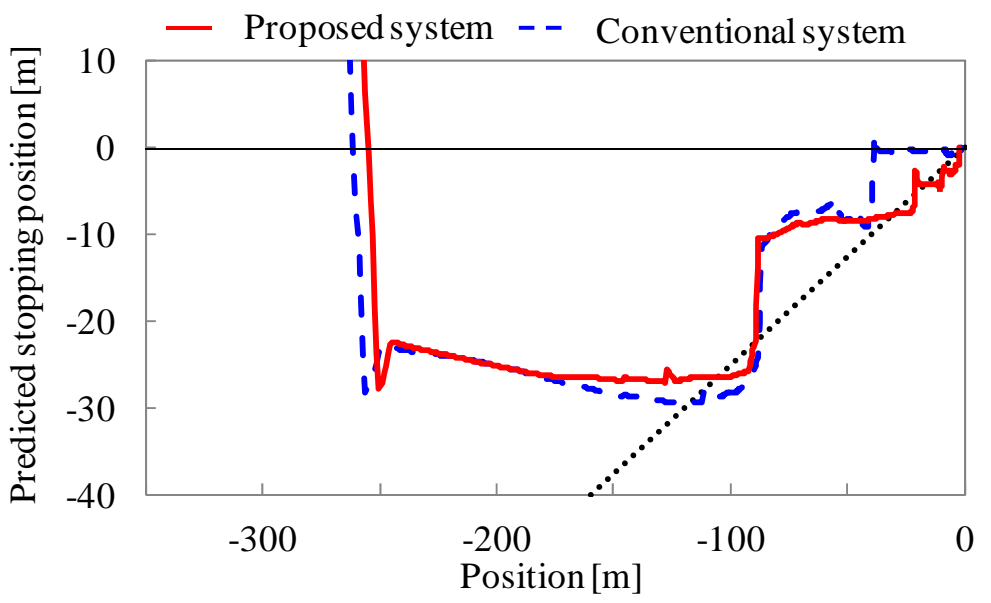

Fig. 4 Transition of predicted stopping position (Subject A, Section 2)

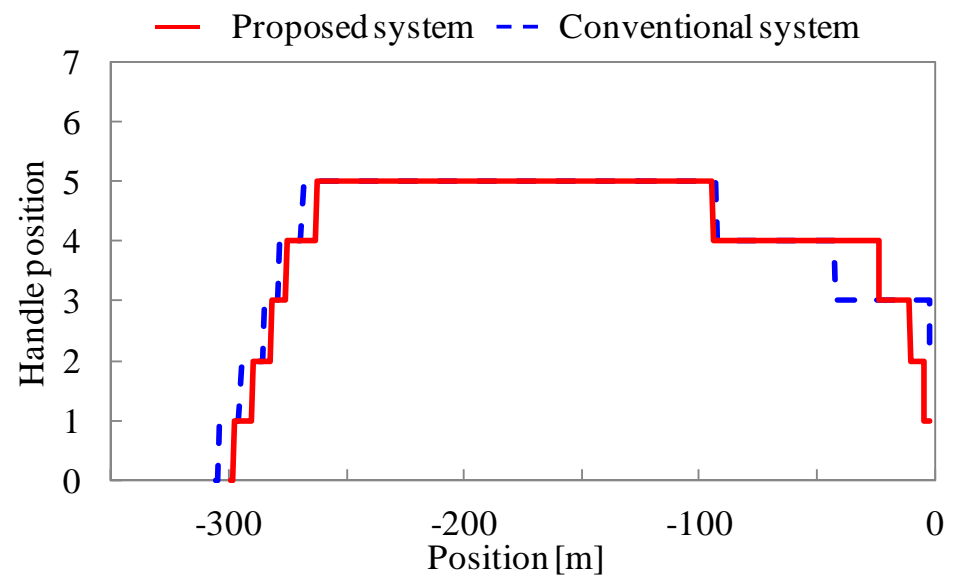

Fig. 5 Transition of brake handle position (Subject A, Section 2)

\section{$4 \cdot 2$ 他の条件における結果}

前節とは異なる条件での結果を確認するために，前節と同じ被験者の異なる区間，および前節と同じ区間の異 なる被験者の結果について検討する.

前節と同じ被験者の異なる区間である第 1 区間の予想停止位置とブレーキ操作の結果をそれぞれ図 6 および図 7 に示す．図 6 に示した予想停止位置の推移では，第 2 区間ほど顕著な差は見られないが，本研究で提案した支 援システムの方が，予想停止位置は目標停止位置に対して手前側を推移して，比較的余裕を持っている状況であ ることがわかる. 図 7 のブレーキ操作の推移でも, 顕著な差は確認できないが, 目標停止位置に近づくにつれて, 目標停止位置までの距離に対して，従来の支援システムの方が大きなブレーキ操作になっていることが確認でき る. 


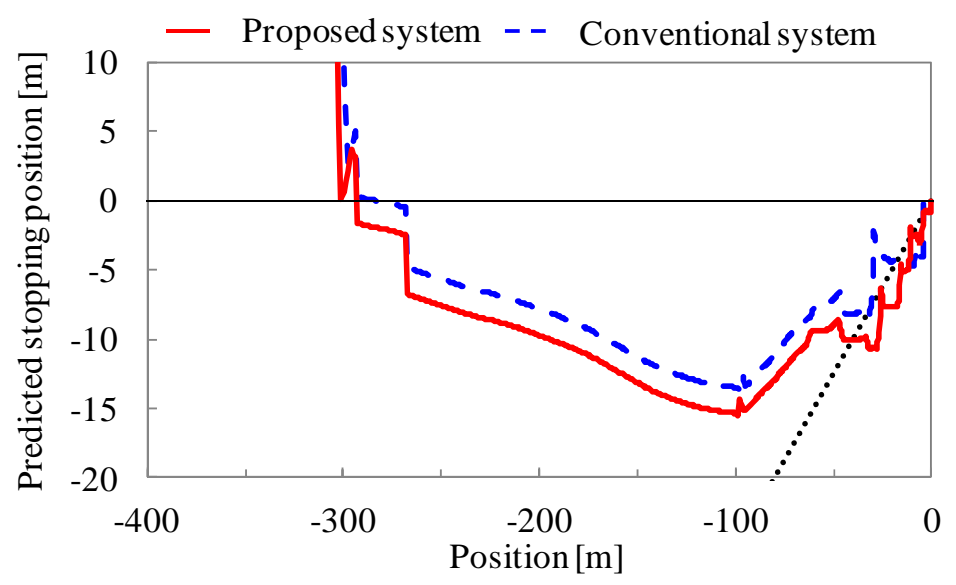

Fig. 6 Transition of predicted stopping position (Subject A, Section 1)

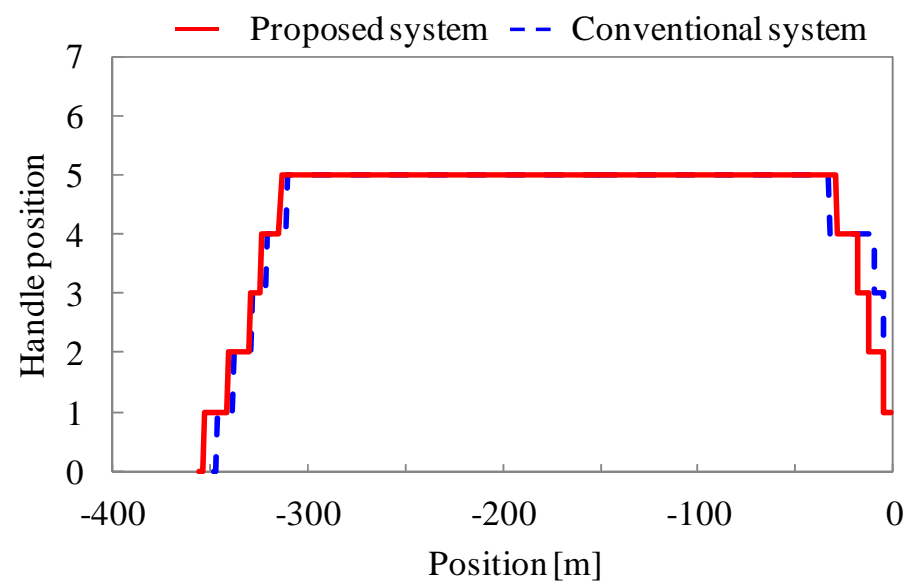

Fig. 7 Transition of brake handle position (Subject A, Section 1)

次に，前節と同じ区間において，異なる被験者である被験者 $\mathrm{B}$ の結果を図 8 および図 9 に示す. 図 8 に示した 予想停止位置の推移に着目すると，被験者 $\mathrm{A}$ と同様に，従来の支援システムを用いた場合では，-40m 付近で予 想停止位置が目標停止位置付近を推移し，余裕がない状態で目標停止位置へ停止している。しかし，本研究で提 案した支援システムでは，予想停止位置は，目標停止位置へ負の值から徐々に推移しており，点線で示した境界 線付近を推移しながら目標停止位置に近づいていることがわかる. 図 9 に示したブレーキ操作の推移も同様に, 従来の支援システムを用いた場合には， $-40 \mathrm{~m}$ 付近でブレーキを緩めたことにより，予想停止位置が目標停止位 置付近を推移してしまい，比較的強いブレーキで目標停止位置に近づいていることがわかる. 本研究で提案した 支援システムを用いた場合には，ブレーキを徐々に緩め，弱いブレーキ操作で停止していることが確認できる.

その他, 上記以外の被験者においても, 本研究で提案した支援システムを用いた場合には, 予想停止位置は負 の值から徐々に目標停止位置へ推移し，弱いブレーキ操作で停止することが確認された．一方，従来の支援シス テムを用いた場合には，本研究で提案したシステムを用いた場合のように推移する傾向も見られたが，予想停止 位置が目標予想位置に近い值を推移寸ることがあり，その結果ブレーキ操作を緩めることができず，停止時に比 較的強いブレーキ操作で停止する場面が見られた. 


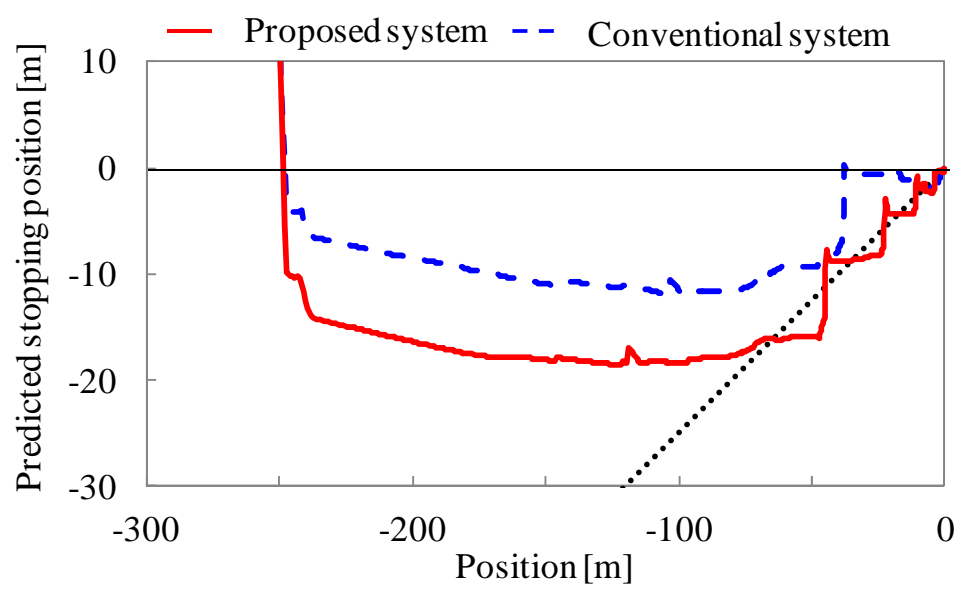

Fig. 8 Transition of predicted stopping position (Subject B, Section 2)

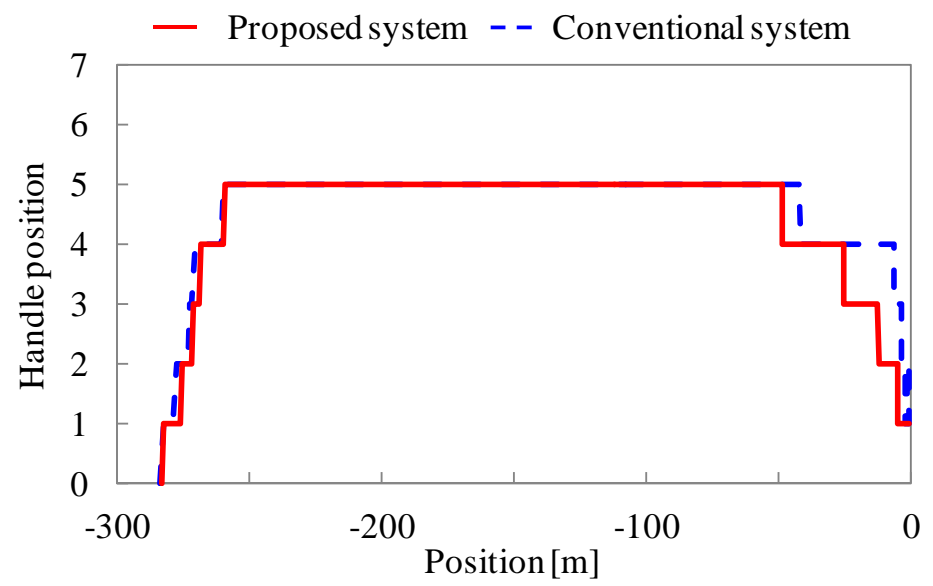

Fig. 9 Transition of brake handle position (Subject B, Section 2)

\section{$4 \cdot 3$ 停止直前の減速度の評価}

これまでに確認された停止時の状態を定量的に評価する，ブレーキ操作に着目すると，停止直前でブレーキを 緩めても減速度が減少しきらない場合があるため, 停止直前の減速度を評価するものとする．停止の寸前では, シミュレータ内で計算されている車両の動特性により, 減速度によらず減速度が一端上昇するため, 停止 $1 \mathrm{~s}$ 前の 減速度について着目する。

図 10 に停止 $1 \mathrm{~s}$ 前の減速度の平均值を示す. 同図には被験者 5 名が 2 走行した計 10 走行分の結果が示されてい る.この図より，本研究で提案した支援システムを用いた場合には，従来の支援システムを用いた場合と比較し て, どの区間においても減速度の平均值が低くなっている. また, 標準偏差に着目すると, 前節で述べたように, 従来のシステムでも弱い減速度で停止する場面も確認されたが，比較的強い減速度で停止する場面も見られたた め, その結果, 標準偏差が大きくなっていることがわかる. 一方, 本研究で提案したシステムでは, 標準偏差が 小さくなっていることから, 停止直前の減速度を再現性良く抑えられていることが確認できる. 本研究で提案し たシステムが, 従来のシステムに対して停止直前の減速度を低減させるという仮説のもとで, 計 10 走行分のデー タについて, 被験者と走行回数で対応のある $\mathrm{t}$ 検定を行ったところ, すべての区間において危険率 $5 \%$ 未満で有意 な差が確認された。 よって, 本研究で提案したシステムが, 停止直前の減速度を抑えることに有効であることが 示された. 


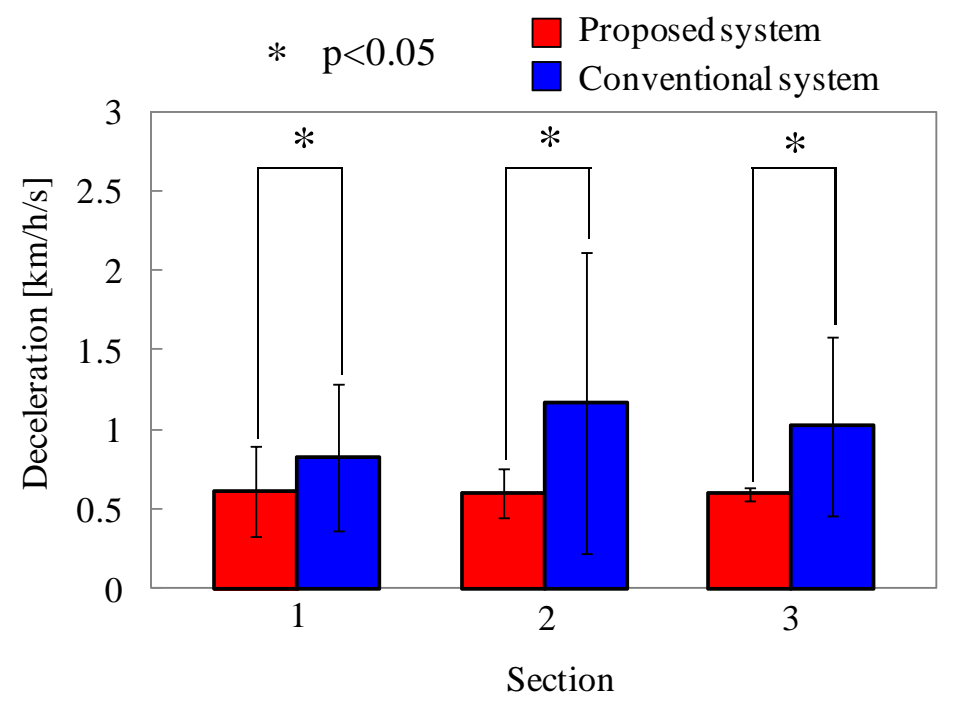

Fig. 10 Deceleration before stopping

\section{5. 結 論}

本研究では，駅停止時に予想される停止位置を運転士に視覚的に呈示し，予想される位置により呈示する色を 変化させること, 所定の位置にブレーキを緩めながら停止する支援システムについて, 列車運転シミュレータを 用いた実験により検討した結果, 以下の結論を得た.

1. 従来の減速度一定を想定した支援システムを用いた場合には，ブレーキ操作の修正等は見られなかったも のの，比較的強い減速度で停止する場面が確認された，一方，本研究で提案したジャーク一定減速を想定 した支援システムを用いることで，段階的にブレーキを緩め，停止時に弱い減速度で停止することが可能 となった.

2. 停止直前の減速度に着目したところ, 提案した支援システムを用いることで，全区間において減速度が有 意に低減することが確認され，本研究で提案した支援システムの有効性が確認できた.

なお, 本研究では, 副次課題の正答率のみしか議論は行わなかったが, 副次課題が主課題である運転操作に及 ぼす影響について，心的な負荷と負担は異なるものであり，支援システムの効果を詳細に議論する上では，メン タルワークロード(7),(8)の観点から検討することが重要であるといえる.

また，主課題である運転操作において，運行ダイヤのような時間的制約は設けなかったが，提案するシステム のようにブレーキを緩めるような支援を行った場合には，一部の区間で運転時分が有意に延びる傾向が確認され た．さらに，いずれのシステムであっても，ブレーキ操作が遅れた場合には，そもそもオーバーランを防止する ことが難しいことから，今後は運転時分も考慮して，適切なブレーキ開始タイミングを呈示寸る支援についても 検討する予定である.

\section{謝 辞}

本研究の一部は，科学研究費若手研究(B)21710171「列車運転士の認知・判断支援によるオーバーラン抑制」の 補助を受けた。記して謝意を示す。

付 録

ジャーク一定で減速する場合と，減速度一定で減速する場合の車両の停止距離の計算過程を示す．ジャーク一 定および減速度一定で減速する場合の加速度，速度および位置の時間応答を図 A1 に示寸．実線がジャーク一定 で減速する場合，破線が減速度一定で減速する場合の応答である。いずれの条件も初期值は，速度 $v(0)=v_{0}$, 加 
速度 $a(0)=a_{0} （ た た ゙ し ， a_{0}<0 ）$ であり，ジャーク一定条件では，ジャーク $j(0)=j_{0}$ とした．停止までに要する時間 は, 減速度一定およびジャーク一定の場合をそれぞれ $t_{a}$ およ゙゙ $t_{j}$ として, 停止時には, 減速度一定で停止する場 合には, $a\left(t_{a}\right)=a_{0}$, ジャーク一定で減速する場合には, $a\left(t_{j}\right)=0, j\left(t_{j}\right)=j_{0}$ になるものとする.

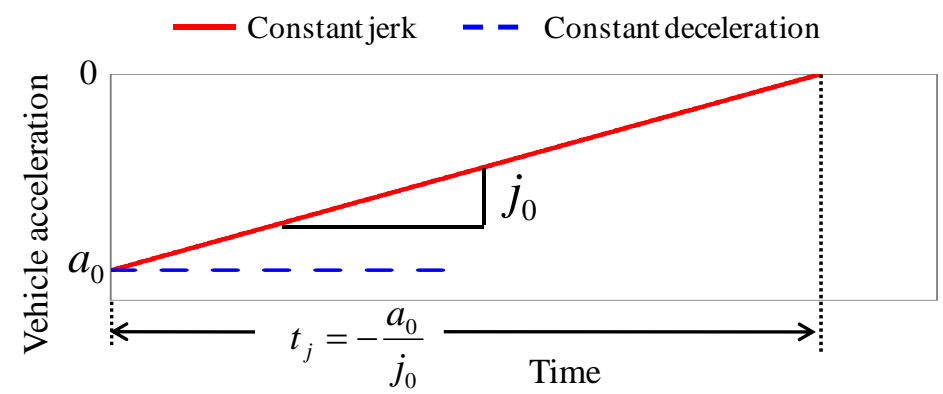

(a) Vehicle aeceleration

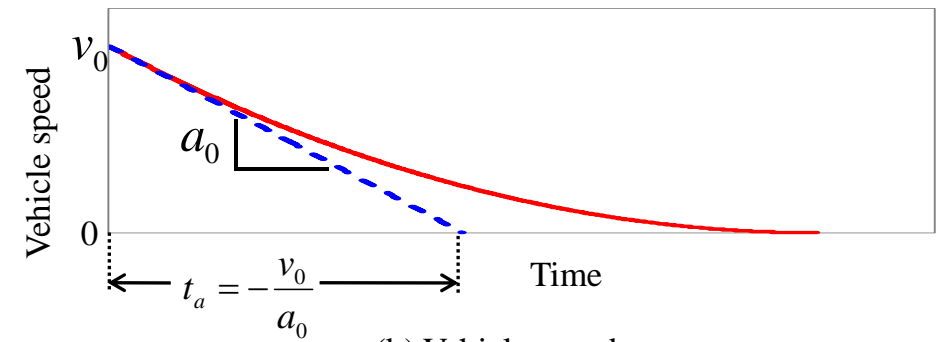

(b) Vehicle speed

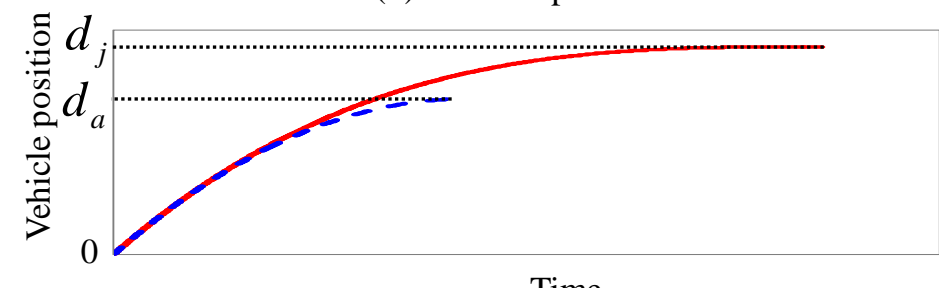

(c) Vehicle position

Fig. A1 Time history with constant jerk and deceleration

まず，減速度が一定で減速する場合には，図 A1(a)に示したように，加速度は常に $a_{0}$ であるため，図 A1(b)の速 度の応答は

$$
v(t)=a_{0} t+v_{0}
$$

と表され, $v\left(t_{a}\right)=0$ であるので,

$$
t_{a}=-\frac{v_{0}}{a_{0}}
$$

となる.このときの車両位置は図 A1(c)のように推移し, 停止に要する距離を $d_{a}$ とすると, 次式のようになり, 式(1)が導かれる.

$$
d_{a}=\int_{0}^{t_{a}} v(t) d t=\int_{0}^{t_{a}}\left(a_{0} t+v_{0}\right) d t=\left[\frac{1}{2} a_{0} t^{2}+v_{0} t\right]_{0}^{t_{a}}=-\frac{v_{0}^{2}}{2 a_{0}}
$$

次に, ジャークが一定で減速する場合には，図 A1(a)に示した加速度の傾きが $j_{0}$ であるので, 加速度の応答は,

$$
a(t)=j_{0} t+a_{0}
$$

と表され， $a\left(t_{j}\right)=0$ であるので， 


$$
j_{0}=-\frac{a_{0}}{t_{j}}
$$

となる．また，図 A1(b)の速度の応答は放物線となり，次式で表すことができる.

$$
v(t)=\frac{1}{2} j_{0} t^{2}+a_{0} t+v_{0}
$$

$v\left(t_{j}\right)=0$ であるので，式(A5)より $j_{0}$ を消去すると，

$$
t_{j}=-\frac{2 v_{0}}{a_{0}}
$$

となる.このときの車両位置は図 A1(c)のように推移し, 停止に要する距離を $d_{j}$ とすると, 次式のようになり, 式(2)が導かれる.

$$
d_{j}=\int_{0}^{t_{j}} v(t) d t=\int_{0}^{t_{j}}\left(\frac{1}{2} j_{0} t^{2}+a_{0} t+v_{0}\right) d t=\left[\frac{1}{6} j_{0} t^{3}+\frac{1}{2} a_{0} t^{2}+v_{0} t\right]_{0}^{t_{j}}=-\frac{2 v_{0}^{2}}{3 a_{0}}
$$

\section{文献}

（1）四ノ宮章, “鉄道安全へのヒューマンファクター研究の取り組み”，信頼性，Vol. 23， No. 2 (2001), pp.186-193.

（2）航空 - 鉄道事故調查委員会, “鉄道事故調査報告書 西日本旅客鉄道株式会社福知山線塚口駅～尼崎駅間列車脱線 事故”, RA2007-3-1, (2007).

（3）丸茂喜高，佐藤洋康，綱島均，小島崇，“列車運転士の駅停止支援システムに関する研究（予想停止位置呈示によ る運転士の認知・判断支援)”，日本機械学会論文集 C 編，Vol. 76， No. 770 (2010)，pp.2500-2507.

(4) 小島崇, 綱島均, 塩沢友規, 高田宗樹, “人間一機械系評価用列車運転シミュレータの開発と脳機能計測への適用”, 信頼性，Vol. 26， No. 7 (2004), pp.617-626.

(5) Gronwall, D. M., "Paced Auditory Serial-Addition Task: A Measure of Recovery from Concussion”, Perceptual and Motor Skills, Vol.44, No.2 (1977), pp.367-373.

（6）例えば, 鈴木桂輔, 岡田雄太, “指尖脈波のゆらぎ解析によるドライバの心理状態の推定”, 日本機械学会論文集 C 編, Vol. 74, No. 743 (2008), pp. 1765-1774.

(7) 芳賀繁，“メンタルワークロードの測定と注意リソースの測定”，人間工学，Vol. 29， No. 6 (1993), pp. 349-352.

（8）芳賀繁，“ワークロード”，産業・組織心理学研究，Vol. 10， No. 2 (1997)， pp. 111-119. 